\title{
RESEARCH
}

\section{Terminological Games: The Finnish Security Police Monitoring the Far-Right Movements in Finland During the Cold War}

\author{
Tommi Kotonen \\ University of Jyväskylä, FI \\ tommi.kotonen@jyu.fi
}

\begin{abstract}
This article focuses on the use of terms and concepts related to the nationalist movements by the Finnish security police during the Cold War. The key objective of the security police was to protect the legal order of the state and monitor the groups and phenomena potentially harmful to that cause. The previous experience regarding the rise of the radical nationalism and fascism in Finland in the 1930s and the 1947 Paris peace treaties were the historical and legal contexts within which the interpretations were made. As the article shows, interpretation made by the security police, however, relied occasionally on a limited understanding about the evolving far-right scene, thus producing terminological confusions, and in some cases even evidently biased interpretative patterns may be observed. The article also studies how terms and concepts produce differing evaluations and differing understandings regarding the phenomena at hand. The analysis is supplemented by a short excursion on the other side exploring how the far-right used the terms in order to avoid police scrutiny.
\end{abstract}

Keywords: fascism; far-right; extremism; radical right; Finnish security police; conceptual history

In this article I study the terms and concepts used about the nationalist right-wing movements in Finland during the Cold War. My main focus is on uses of the terms 'fascism', 'Nazism', and 'the extreme right' by the Finnish security police, which I will contrast with the interpretations made by the far-right groups themselves. Concepts and terms were rarely addressed directly by the security police, sometimes almost entirely lacking the criteria for their application and thus the point of reference (cf. Skinner 1989), and in most of the cases the scope of their use is revealed only in practices and classifications of the police. What they chose to monitor was, in the end, based on their own understanding of the terms and concepts concerned. How concepts were understood was in this case not just a linguistic matter, but it affected the situation reports, and thus indirectly the decision making at the political level. The analysis presented within this article is not an extensive analysis of the usage of terms and concepts in Finnish discussion but highlights certain consequences and 
problems in language used by the authorities. The lack of conceptual clarity and insufficient monitoring became real problems in the late 1970s, when Finnish neo-Nazis started a terror campaign (cf. Berger 2019).

As has been pointed out by Swedish scholar Heléne Lööw (2017), there is still a lack of detailed studies on the concepts and terms used at the field of extremism and public security, including how the concepts are used at the operational level, and what their effects are. Due to the restricted access to the archives of the security and intelligence services, most of the analysis done so far has focused upon their public statements, and, in some rare cases, have drawn data from interviews with the members of the organizations in question (cf. e.g. Warrington 2018). From the perspective of conceptual analysis, the uses and definitions of concepts and terms by the intelligence services are an interesting case, as the concepts used were rarely explicitly defined and may often be observed only through their operational practices (cf. Eriksson 2016). ${ }^{1}$ The conceptual choices are also typically made outside the public scrutiny and the lack conceptual clarity is, as observed by Gunilla Eriksson (ibid., 106), occasionally an intentional act to ensure that concepts can be used in a variety of contexts and but also to 'avoid bickering over concepts themselves'. This also implies a certain conservatism in the use of concepts; within the intelligence services there may be some reluctance in adopting new concepts to avoid confusion (ibid.).

Especially in the 1970s the word 'fascism' was often used in Finland quite liberally, and also as a stigma word against any kind of opposition (cf. Hatzidaki \& Goutsos 2017); it was additionally used as an evaluative and normative concept (cf. Jackson 2019), foremost due to the peace treaty between Finland and the Allies, in which 'fascism' was present as a particularly normative word. By examining their linguistic conventions, I will ask whether Finnish authorities used the less normative expression 'extreme right' instead to justify their inaction or lack of interest in monitoring far-right groups. By choosing a neologism it was also possible to avoid the negative historical connotations and to keep away from discussing the terms of the peace treaty. To avoid undesirable conclusions, terms and concepts were also often used non-evaluatively, that is, descriptively (cf. Skinner 1989).

Before WWII, Finland had a relatively large and active far-right scene, ranging from openly fascist groups to parties claiming to represent traditional nationalism (Silvennoinen, Tikka \& Roselius 2016; Ekberg 1991). After WWII, however, fascist movements were targeted explicitly in the Paris Peace Treaty between Finland and the Allies (hereafter 'the peace treaty'). It was from there on the duty of the Finnish authorities to observe and, if necessary, to even ban the movements aiming at revitalization of fascism in Finland. The peace treaty remained one of the key points of reference in Finnish politics until the early 1990s and was regularly referred to, for example, in parliamentary debates on security issues. Besides ordering compensation for the losses or damages caused to the Allies, the treaty, for example, limited the size of the Finnish military.

Article 8 of the peace treaty stated that Finland has taken measures 'for dissolving all organizations of a fascist type on Finnish territory, whether political, military or para-military, as well as other organizations conducting propaganda hostile to the Soviet Union or to any of the other United Nations', and Finland 'shall not permit in the future the existence and activities of organizations of that nature which have as their aim denial to the people of their democratic rights (Treaties of peace with Italy, Bulgaria, Hungary, Roumania, and Finland 1947). These clauses were, however, interpreted in a wide variety of ways, which did not always even try to follow their spirit.

${ }^{1}$ One may note, however, that certain emerging fields of study, such as surveillance studies, may produce interesting analysis on the activities of the intelligence services, although their focus tends to be more on personal surveillance and technology (cf. e.g. Lyon 2007). 
Despite the treaty, some groups advocating National Socialism grew also after the war. To avoid the ban because of the peace treaty, Finnish far-right groups defined terms and concepts quite innovatively, which will be described in this article. Also, the authorities had relatively flexible and imaginative interpretations on the contents of fascism or similar phenomena, and the whole palette of means for conceptual redescriptions (cf. Skinner 1997, 138-180) was in use. By these means, revolutionary movements could, for example, be defined as protectors of the current political system and a vice was thus turned into a virtue. More typical, however, was diminishing rhetoric, where groups or actors were seen as unimportant and the limit of classifying something as fascist was narrowed.

The Finnish security police, officially Finnish Security Intelligence Service, Suojelupoliisi or, colloquially, Supo in Finnish, was created in 1949 amidst the so-called years of danger, by which is meant the threat of alleged communist takeover in the late 1940s. Arguably, by then and after losing the 1948 elections, the communists had already lost their momentum (cf. Rentola 1997), but due to the Soviet influence in Finnish politics the surveillance of communist activism was seen continuously as a key priority. Suojelupoliisi, which can be translated into English as 'protection police', was founded in 1949 after communists lost control of the Interior Ministry and the former security police, Valtiollinen Poliisi (Valpo) (in English 'state police'), was disbanded. Valpo had been accused of several misconducts, and its surveillance activities were said to be biased - they focused only on the far-right or nationalist organizations. After reorganization of the security police and founding of the Supo, one might argue that the bias continued, but this time in the opposite direction. The public manifestations of fascism could cause harm for the foreign policy of Finland, especially when noted by the Soviets, and therefore keeping such phenomena out of sight was seen important by the Supo, but also by the political leadership of the country. Countering far-right activism was justified explicitly by the possible Soviet reactions even when the far-right organizations were otherwise estimated as irrelevant (cf. letter by Urho Kekkonen to Eino Uusitalo, 20.8.1977, UKA).

Conceptual shell games did not of course end by the end of the Cold War. Even current-day far-right movements use veiled rhetoric, fuzzy concepts and double-talk in order to differentiate themselves from notorious skinheads or neo-Nazis. There are also practical reasons behind the double-talk: in several countries, National Socialism is banned as an ideology, as are other forms of extremism considered to be against principles of democracy. Therefore, groups often try to use coded language (cf. Vaarakallio 2015) and organize in such a way that it is difficult to ban them: for example, in Germany the extreme right has used both party formats and autonomous cell structures when trying to circumvent the attempts to outlaw them. Analysis of earlier conceptualizations may be also useful in deciding how to counter current movements: in historical analysis the whole process and its outcome is visible, including possible blind spots in conceptualizations and also the actual escalation of violence followed by these conceptualizations.

In this article, for the sake of clarity, I will use 'far-right' as an umbrella term to describe all the manifestations of radical and exclusive nationalism in Finland, which typically included extra-parliamentary groups; I will use more specific terms when discussing groups and actors in detail (cf. Art 2011; Bjørgo \& Berntzen 2019; Mudde 2002; Shekhovtsov 2018). The far-right groups in question share an ideology based on exclusive nationalism, which sees the people and the state as one homogenous unit and foreigners as a threat to this community. They imbue a nation with a value that surpasses the value of human rights and fundamental freedoms (Shekhovtsov 2018). Despite scholarly disagreements, and even though what should be put under this umbrella term is still questionable, 'far-right' is the only term that has been to a certain degree established among researchers, although the criteria for the use of the term may still differ. 


\section{Research Material}

Key source material for this article consists of the Finnish Security Police's (Supo) surveillance reports, person files and cards, and files on far-right groups. The material is of varying quality and produced by the detectives, inspectors, and occasionally also by the leading figures of Supo. The target audience varies too: some of the reports were for internal use only, some of them were produced after parliamentary inquiries and were public. Although intended for a limited audience, internal memos written by the local inspectors are also interesting here, as they may have been used to persuade the leading figures of Supo into action or inaction regarding some group under scrutiny. From the perspective of this article it is of course necessary to acknowledge that concepts and terms were also often chosen on an ad hoc basis without much premeditation. Despite this, I argue that there are discernible patterns in their use.

The article is based on extensive archival work at the archives of the Finnish Security Intelligence Service and other relevant archives conducted between years 2014 and 2017. The security police archival documents in Finland are open to all interested only after 60 years of their date of issue. However, for the purpose of scientific research, the newer material can also be consulted. Researchers may be given a permit to study unredacted documents older than 25 years, as was the case with this research project. Certain other limitations apply as well: documents may not be copied or photographed, and the researchers are only allowed to take notes; perhaps more important from the perspective of this study is that the full archive is not available to researchers, who may only consult documents related to their research topic. Furthermore, officials are the ones who decide whether documents requested are within the limits of a research permit, and occasionally access may be denied to some documents based on their alleged irrelevance for the topic at hand. Therefore, it was not possible to consult extensively, for example, the material concerning Supo's leadership and their decisions regarding the focus of investigations, although other studies have covered that to some extent (see esp. Rentola 2009). The possible gaps in material could also be filled in by consulting certain other archives, including especially the archives of President Urho Kekkonen and the National Bureau of Investigation. Additionally, the report series at the Supo's archive on far-right movements appeared to be intact and studying the operative level was therefore possible.

\section{The Far-Right Terminology Used by Scholars and Authorities}

In the international scholarly literature, there are no concepts or terms generally accepted when describing far-right groups or ideology. Despite Roger Griffin (2002; cf. Bötticher 2017a) claiming consensus on the generic term 'fascism', this is not correct besides perhaps its use among certain British scholars. German writers, for example, use the term much more cautiously. In Germany, the term 'right-wing extremism' (Rechtsextremismus) is on the other hand quite generally accepted (Virchow 2017, 14). The office for protecting the constitution (Verfassungsschutz) gave in 1974 a clear-cut definition of what constitutes radicalism and extremism that was subsequently used also by the German constitutional court, creating a legal disposition: ${ }^{2}$

The term 'extremist' takes [...] into account the fact that political activities or organizations are not already hostile to the constitution if they have a certain aim that goes all the way to the roots of a question, although it might be 'radical' according to the

\footnotetext{
${ }^{2}$ Nevertheless, the German constitution refers to these groups with the term 'Verfassungswidrigkeit', i.e. anticonstitutionality, which is the legal basis on which the constitutional court judges the relevant cases.
} 
common use of the word. They are 'extremist' and therefore hostile to the constitution in the legal sense only if they are directed toward the [...] foundations of our liberal democratic basic order. (cit. Backes 2009, 148)

This terminology and conceptualization is not however uncontested either: several scholars have for example noted that the extremism discourse comes quite close to the older totalitarianism debate in lumping together all forms of extremism, and puts in question even certain radical ideas even when those may be seen as supporting and strengthening the democratic system (Sörbom \& Wennerhag 2016). Holger Oppenhäuser (2011) has also noted, that the extremism discourse normalizes the middle position - and is, as he notes, at odds with the famous class-based formulation of S.M. Lipset on fascism as 'extremism of the centre'. The concept of extremism then suggests that the current status quo is normal and defensible, despite its actual form and appearance; seen from this formal perspective, one might consider people opposing Hitler as extremists. Some scholars have also warned about the problem of blurring the distinction between terrorism and extremism (Onursal \& Kirkpatrick 2019).

Of some concern is also that the proponents of the extremism definition often rely on biological metaphors, when referring to extremism for example as a disease (Oppenhäuser 2011, 48). Biological metaphors on extremism, however, date back, at least, to the 1930s (Backes 1989, 60). One example of recent Finnish discussion shows also similar tendencies: the chief of the national police board referred to the right-wing extremism as a disease, stating that we need to choose 'drugs by disease' and thus to exclude them from a 'healthy' community (Helsingin Sanomat 19.9.2016; cf. Koselleck 2004, 157).

In her recent dissertation, Astrid Bötticher (2017b) has presented a detailed analysis of the terms radicalism and extremism in the German context. In summarizing her results she notes that 'in terms of histories of ideas, radicalism and extremism stem from different socio-political (party) movements' (Bötticher 2017a). This has been observable also in Finland. Especially before the 1990s, radicalism was regularly associated with the political left and was often seen more positively than extremism. Somewhat tellingly, in the late 1960 s a member of the Finnish parliament Pertti Salolainen wanted specifically to emphasize that there is also radicalism on the right and declared he is a right-wing radical (Kotonen 2018, 17). This was done in order to fight back the radicals on the left and their hegemony over the term radical.

In Anglo-American discourse the definition of the extreme right bears similarities with the terms used in Germany, although without any normative basis. Among the most common formulations belongs the division between 'radical right' and 'extreme right', with 'farright' acting as an umbrella term (Bjørgo \& Berntzen 2019) and with an emphasis on the use of violence and anti-democratic tendencies as a demarcation line between radicalism and extremism. However, extremism itself has also been given differing conceptualizations. Seymour Lipset defined for example with Earl Raab $(1970,428)$ 'extremist forms of politics' on the basis that they reject pluralism and favour monism. Highlighting the problems in finding consensus on a definition of the extreme right, Cas Mudde $(2002,11)$ has noted that within the scholarly literature there have been at least 26 different definitions of extremism, and those have relied on 58 different features for defining the term. Luke March and Cas Mudde $(2005,24-25)$ have used a German-type definition, noting that extremists are antidemocratic, whereas radicals are not anti-democrats but against a liberal form of democracy. However, using democracy as sole criterion is also problematic, and, as has been noted by Paul Lucardie (2014), in certain cases one may also speak of democratic extremism. It is also worth noting that extremism is a time- and context-bound concept: what was extreme in the 1930s is not necessarily extreme today and vice versa (Jackson 2019). 
Likewise, when translated to other languages, such as Finnish, the division between radicalism and extremism is not at all clear or simple. In Finland, no consensus on proper terms exists, which opens possibilities for innovative interpretations, as will be shown in the analysis. The use of Finnish equivalent for 'extreme right', äärioikeisto, is in current Finnish discussion the standard, even if laitaoikeisto (far-right) or even fasismi (fascism) have occasionally been used. Other similar terms used in Finland are radikaalioikeisto (radical right), radikaali nationalismi (radical nationalism), and äärinationalismi (extreme nationalism). However, in international comparison it is striking that Finnish discussion rarely differentiates between the concepts laitaoikeisto and äärioikeisto (far-right and extreme right); Finnish extremism vocabulary is used on both populist radical right as well as neo-Nazis.

The Finnish Ministry of Interior uses the term väkivaltainen ekstremismi (violent extremism) and the loanword ekstremismi instead of any of its translation variants. This is, however, mostly used only in the official context and follows the German division between extremism and radicalism (Sisäasiainministeriö 2012). Here, the stress is on the use of violence and not on the ideology per se, and authorities stress that extremism, unlike radicalism, is antidemocratic. The similar term 'violent extremism' (våldsbejakande ekstremism) has also been used, for example, by the Swedish security authorities (SOU 2013, 81). This approach is not without problems, either. When focusing on means instead of ideology as a sign of 'radicalization' and securitizing the issue, ${ }^{3}$ preparing ground for violent activities is ignored or given less attention, and the whole debate is depoliticized. For, even when used non-violently, heated rhetoric may be harmful to the democratic system. Movements also have different phases and can oscillate between violent and non-violent phases, and therefore, as argued by J.M. Berger (2019), the implicit assumption that not all extremists are violent is problematic. Furthermore, one may question which actions should be considered as violent, and these classifications are not at all unproblematic. Susanne Feustel (2011) has, for example, noted that classifications and statistics may be used to give a false picture about which groups constitute an actual threat.

Both in the international as well as in the Finnish discourse the spatial metaphors have been favoured instead of the temporal - an example of the latter being the reactionary-progressive axis, which is a rarity within the current scholarly literature. The spatial metaphors tend to divide the political space asymmetrically (cf. Backes 2006, 236), favouring moderation. Going to the extreme is a vice, but following the golden middle way a virtue. One might of course argue that this is not the case with vertical metaphors, such as radicalism, which may perhaps more easily be seen also as a virtue.

\section{Blind in the Right Eye? Finnish Security Police Monitoring the Far-Right}

'Äärioikeisto' (extreme right) is a neologism in Finnish and the earliest examples of its use may be found in the early 1960s. As Uwe Backes (2006) has pointed out, the first ones to use the extremist terminology on far-right or fascist groups have been the centrists: Italian Luigi Sturzo, who was one of the founders of the Italian People's Party, has been recorded as a first one to call the fascists estremistri di destra, an Italian equivalent of right-wing extremists. In Finland the evolution of the term is similar. The earliest similar Finnish formulation - äärimmäinen oikeisto (the most extreme right) - was used by the members of the centrist Agrarian League about the fascist Isänmaallinen Kansanliike (Patriotic People's Front) in the 1930s. ${ }^{4}$

\footnotetext{
${ }^{3}$ On the discursive construction of security, see e.g. Buzan et al. (1998).

${ }^{4}$ The Isänmaallinen kansanliike (Patriotic People's Front) was a party founded in the early 1930s by the members of the far-right Lappo Movement after the latter's unsuccessful coup attempt in 1932. Their ideology and aesthetics bear strong resemblances with the Italian Fascist party. The party was banned in 1944.
} 
The term 'radical right' had however been used already in the 1920s in reference to growing nationalist movements abroad, especially in Germany (Kotonen 2018; Kotonen 2015).

The observation of the radical, anti-democratic movements was a key responsibility of the Finnish Security Police, Supo. Supo's official purpose was, as its name also suggested, to protect the legal order of the state on a neutral basis (Pohjonen 1999, 71, 80). As the first leader of the Supo emphasized, "no legal parties should be monitored more than is necessary for compiling reports' (ibid., 80).

However, in practice, Supo focused its operations on the far-left and communist organizations. The far-right was not a key priority and was not, until the mid-1970s, even followed and observed very closely (Kotonen 2018; Rentola 2008). The first and, until 1970, also the only new person file for a person unrelated to the communist activities was opened in 1955 for a former national socialist (Rentola 1999, 113-157, 140) - this was during a time period when altogether 1613 person files were opened. A person card series, which typically is more concise than person files, was opened for far-right activists in the early 1970s, and around 200 persons were added to the card system by the late 1980s.

The focus on communism was, arguably, relatively typical for all the West European security police organizations during the Cold War (see e.g. Stortinget 1996), although there were certain obvious national idiosyncrasies in their operational conduct. Supo's bias is even more explicit when considering the fact that they employed several former far-right activists, among them members of the 1930s fascist organizations Lappo Movement and Patriotic People's Front. The first leader of the Supo, Armas Alhava, who acted as a chief until the early 1970s, was a career policeman but had also allegedly cooperated with the Gestapo in his time in the police office during the WWII. This, however, was not unheard of in other countries as well. In West Germany, several former Gestapo officers were hired by the security police (Goschler \& Wala 2015, 353-366). The foreign intelligence service was founded by a former Abwehr and Sicherheitsdienst officer, Reinhard Gehlen, who enlisted several of his former associates from the intelligence services of Nazi Germany.

The filing system of the Supo is to some extent already revealing. When filing reports on far-right actors and organizations, Supo used the old filing system, which was already in use by their predecessor, Valpo. The reports were collected in files on 'organizations disbanded after the 1944 interim peace and their possible continuation' and 'secret societies'. This implicates that the new forms of far-right activism were not keenly observed or were interpreted in relation to pre-war movements and the Paris peace treaty. In one of their memorandums following a parliamentary inquiry this is also made explicit: 'According to the information of the security police, there are no groups in Finland violating the peace treaty' (PM 16.5.1972, Supo). In that note, Supo also lists organizations banned after the war, which suggests that these were the groups they were (and should have been) focusing on. This assumption is also confirmed by the fact that, in their assessments, the police took notice of whether there were any contacts to former members of the banned organizations. One can easily come to the conclusion that, in order to minimize the importance of the phenomenon itself and to justify the lack of their surveillance over the far-right groups, Supo resorted to a narrow legal definition in interpreting the rise of fascism and related phenomena - at least when asked to report to politicians.

For the above reasons, it seems that the reorganization and new forms of fascist post-war activism was not of interest for Supo, or they did not interpret them as harmful. It is for example noticeable that, although a group of Finnish activists joined in 1950s the neo-fascist organization European Social Movement (ESM), this went unnoticed by Supo. ESM avoided explicitly racist and fascist rhetoric, even though its leadership council included several wellknown fascists like Oswald Mosley and former Republic of Salò official Augusto de Marsanich. 
Some Finns were also in regular correspondence with one of the organizers of ESM, the Swedish fascist Per Engdahl. There are no records in Supo's files indicating they ever took note of this development, and no person files or even cards were opened for the Finnish activists in question.

The conceptual differentiation between 'fascism', 'Nazism', and 'extreme right' was a slow process within Supo. In the 1950s these terms were often used as synonyms, but during the 1960s, possibly reflecting the international development and the rise of new movements, they started to refer to different phenomena. In the late 1970s, with the appearance of openly national socialist organizations, the use of the words 'Nazism' and 'extreme right' started to merge again.

The use of the term 'extreme right' was more consistent in the 1970s, and it was used to cover a broader field - and occasionally referred also to some parliamentary parties in Supo's reports. By the 1980s, Supo had seemingly abandoned the term 'fascism' altogether and instead referred to the most extreme part of the nationalist field as 'neo-Nazis'. The more generic, umbrella-type, political concept 'extreme right' formed the basis for police surveillance from there on. The youth culture came also under the loupe. Especially skinhead groups and their racist attacks started to show in the reports (see e.g. the report 'Extreme right movements in the Helsinki region', 1987, Supo).

By differentiating between 'fascism' and 'extreme right' Supo was able to argue that the phenomenon is not a threat to internal security and does not violate the peace treaty. On the other hand, by securitizing the discussion Supo was able to avoid discussing the possible broader political implications of the rise of the far-right. In similarity to for example Sweden, monitoring was far more extensive when dealing with far-left movements and was expanded to areas that were not strictly a security matter (cf. SOU 2002, 94; SOU 2002, 91). In Finland, far-right activism was also often interpreted as a reaction to the rise of far-left movements. This securitized discourse was, however, off the mark in light of empirical evidence: Finnish neo-Nazis conducted acts that may even be classified as domestic terrorism, whereas political violence on the far left was practically non-existent. The definition of concepts, although nowhere done explicitly, relied thus on Supo's interpretation of its key tasks and on what constituted a threat. The following analysis of Supo reporting also shows a pattern of minimization.

\section{Supo's Interpretational Practices}

Supo's interpretation of fascism or neo-fascism was based on explicit formulations and symbols used by the groups analyzed, and they tried to find direct declarations of fascist or national socialist intentions. When faced with veiled rhetoric, they were more or less puzzled. One interesting example of misguided analysis is from the early 1960s when they took notice of a new group, the Finnish Workers' Front (Suomalaisen Työväen Rintama), promoting 'neorevisionism'. Although the group's programme discussed the idea of a corporate constitution and blood-and-soil ideology in explicit revolutionary terms, Supo did not even mention fascism or Nazism in their analysis but chose to redescribe the contents of the programme in nationalist and class-based terms.

The chief of office at Supo, Anselmi Mäkelä, reported that the group is of 'no danger to the state', and is 'neither communist nor bourgeois' but 'aims at some kind of an idealistic thousand-year national state'. Inspector Toimi Arra, himself a former member of the fascist Patriotic People's Front, wrote that the programme has 'some bourgeois elements, or at least those are tolerated. One could almost think this programme is written by someone belonging to the current center, seducing the workers but not entirely forgetting the bourgeois either'. (Ilm. 584/2.2.1962, Supo.) The 'third way' nature of fascism (Mosse 1980), let alone its 
subsequent conceptualization as 'extremism of the centre' (Lipset 1960) seem to have eluded the analysts, although the omissions are probably intentional considering especially Arra's background. Even the phrase 'thousand-year state', an explicit reference to the Third Reich, did not attract much interest.

However, Supo continued the surveillance of the Finnish Workers' Front, which later rebranded itself as Society for the Finnish Unity dropping also the most explicit fascist rhetoric from their programme. In the late 1960s, when neo-Nazism was on the rise, for example, in West Germany, its surveillance was justified on the basis that 'neo-Nazism may gain foothold among its ranks'. But according to Supo, 'nothing of the sort has been noted' (PM 18.11.1966, Supo). Characteristic sign of Supo's understanding of far-right vocabulary is that, when examining whether a group or an actor had fascist or Nazism-inspired ideas, they tried to find foreign contacts, ideas, and symbols. The use of the swastika, ordering foreign neoNazi newspapers and magazines, or admiration of Hitler could qualify as an indication of these ideas.

The problem in Supo's policy lied thus not only in the terminology used and in their strict interpretation of the terms of the peace treaty. The threat they saw in the extreme right was mostly external, produced abroad (cf. Malkki \& Sallamaa 2018). Somewhat tellingly, the first broader investigation of Finnish neo-Nazism in 1966 was conducted only after a neo-Nazi coup plan and a weapons cache were discovered in Sweden. The case was largely publicized, and the Swedish far-right organization was questioned. The Carlberg foundation had also links to Finland, partly prompting Supo to conduct its own investigation as well. Also, in 1974 a Swedish case led to investigations in Finland too. This happened after a series of bomb attacks in Stockholm conducted by the Nordic Reich Party, a national socialist party that also had supporters in Finland.

When finding groups that relied on domestic predecessors as a source of inspiration, Supo occasionally found these groups even useful on the basis that these groups had supported Supo's work in their fight against the extreme left and had defended the current political system - sometimes even taking the programmes of the groups at face value. Most strikingly, even when the connection to the banned organizations and former Nazis was explicit, at least some of the inspectors saw the goals of such groups still in a positive light and thus elevated their motives by redescribing their actions as patriotic (on the rhetorical technique, cf. Skinner 1997, 144). Supo, including the leaders, helped these groups to veil their intentions, possibly also for the sake of deflecting negative attention from the Soviets, and in some cases warned them about the possible negative press (Anselmi Mäkelä 10.3.1960, Supo). This is evident, for example, in a case from the late 1960s, when a group in northern Finland tried to form anew the Patriotic People's Front (Ilm. 490/1.5.1974, Supo). Supo asked them to change their name, but otherwise let them continue their activities. In their analysis, Supo remarked a difference between the group in question and the 'real neo-Nazis'.

The term 'neo-fascist' started to appear in Supo's reports more frequently in the 1970s. However, this phenomenon was interpreted as a continuation of the old forms of fascism, not as some novelty or ideological reorientation - 'fascism' and 'neo-fascism' are used interchangeably. Also noteworthy is that 'fascism' was often interpreted within the narrowest phrasing of the peace treaty as something that involves military exercise or armed drills and an organization.

Typically, Supo described some actors who were active consumers of neo-fascist propaganda as belonging to 'the extreme right, even though they are not fascists'. Here the interpretation is again based on the militant nature of fascism and the peace treaty, with the latter putting emphasis on 'military or para-military organizations'. This very limited interpretation had its consequences: only three months prior to terrorist attacks by a loosely organized neo-Nazi 
group in 1977, Supo deemed them more or less harmless and nothing to worry about in respect to the peace treaty because their armed activities were modest and they had no actual organization (PM 16.8.1977, KRP).

Thus, fascism appeared here for them as a certain form of organized political violence. Regarding Finnish organizations, Supo often kept silent about the second part of the peace treaty, which included an article on fascist organizations, defined by the 'denial to the people of their democratic rights'. At best Supo may have referred to the 'anti-democratic spirit', using the Finnish term 'kansanvalta' (in English 'people's rule') instead of democracy (cf. ilm. 3.4.1958/845, Supo). The only explicit references to a denial of 'democratic rights' are in relation to Swedish neo-Nazis (PM 29.8.1974, UKA).

The concepts of 'far-right' or 'extreme right' are nowhere explicitly defined by Supo, which is not, as mentioned above, atypical for the intelligence services, and highlights the political nature of the services. Distinguishing these terms from the narrowly defined concept of 'fascism', however, also suggests that all non-military forms of anti-Soviet activities and other 'patriotic' endeavours fall under those concepts - and are thus more or less acceptable. Anti-Soviet attitude and strong patriotism are typically discussed in the reports in reference to the extreme right. Occasionally reports also try to dismiss the concepts 'far-right' and 'extreme right', referring for example to the latter as something the media wants to use for stigmatization purposes, or putting the concept in doubt by calling it 'the so-called extreme right'. In a report on 'political extremist currents' in 1973, for example, Supo preferred the term 'radical right' instead of 'far-right' - and symmetrically referred to left-wing movements as 'radical left' (Review 1/73, UKA).

The use of far-right terminology and avoidance of the term 'fascism' by Supo was influenced by the fact that Finland had a strong communist movement, which typically relied on fascist or Nazi terminology. Especially in the 1970s Supo had to respond to, for example, parliamentary inquiries about far-right movements, relying, as mentioned above, often to very narrow and legalistic interpretations. To some extent, one might argue, the far-left usage of the term 'fascism' has also influenced current discussions. Although there are no scholarly analyses of the current far-right terminology in Finland, it is easy to note that the concept of fascism is mostly used by the far left and other commentators may find it stigmatizing. It is, thus, rather a normative statement, not an empirical one.

In the following section, I will analyze the use of far-right terminology by the actors themselves and compare their analysis to those of Supo. The context and focus is on the politics during the 1970s, when discussion on fascism was heated, and several parties started their own 'hunts' for fascists. How the far-right itself defined the relevant terms and concepts was however highly dependent also on Supo's criteria and definitions.

\section{Neo-Nazis Playing Cat and Mouse with the Authorities}

Being an extremist was not necessarily considered as a stigma by far-right actors in Finland in the 1960s. Many members of far-right groups interrogated by Supo accepted the label 'extreme right', but vehemently denied being Nazis or fascists (see e.g. police investigation file 5/1966, Supo).

European far-right movements had tried to solve the dilemma of Nazi-stigma since the end of the WWII. How to deal with the Nazi past was a dividing issue for example within the new European network of former fascists, the European Social Movement, and eventually the group was split in two because of this. By the end of the 1960s, the so-called new right started to emerge in France and also in Germany, taking more distance from the pre-war movements, also terminologically. Setbacks in elections, especially by the German NPD, were one reason behind this reorientation. 
As has been argued by Paul Jackson and Matthew Feldman (2014), double-talk and terminological innovations have been a key element in new far-right movements, and veiled language is their current modus operandi as well. Although using different language when speaking to different audiences is a natural part of politics, and, as argued already by Erving Goffman in the 1950s, a part of social interaction in general, for the far-right 'repackaging' and creating a respectable façade was even more a necessity due to the stigma of war and Holocaust. It is, however, clear that, at least what concerns the movement, its ideology was, and still is, based on the same old biological worldview, even if argued, for example, in the language of 'ethnopluralism' instead of 'white supremacy'. One of the key ideologues of the French new right, Guillaume Faye (2003) has claimed explicitly, that ethnopluralism was just a ruse and was meant to veil the old-school racism, although obviously all of them do not share this opinion. For the old Vichyite and a member of the new right movement, Maurice Bardèche, the biological viewpoints were still relevant, although he accepted the new approach as 'realpolitik of the right' (quoted in Marcus 1995, 23). Some parties have shaped their ideology into right-wing populism, although, at least in some cases, it is apparent that they are still anti-democratic and revolutionary (cf. Copsey 2004).

Terminological innovations were a necessity in Finland as well, already since the peace treaty and mostly because of it. An interesting example of the use of veiled language is the early 1960s movement Finnish Workers' Front, which more or less copied its programme from the fascist movements of the 1930s but named its ideology 'neo-revisionism'. Their programme was later copied almost verbatim by another organization, Patriotic National Movement (Isänmaallinen Kansallisliike), which made explicit connection to the 1930s by adopting its Finnish abbreviation IKL from the most successful fascist organization, Patriotic People's Front.

In the mid 1970s, the key figure in the Finnish far-right scene was Pekka Siitoin, a photographer and occultist who founded a small neo-Nazi party in 1976. Although due to his later behaviour he was described for example as a W.C. Fields type comical Nazi (Kaplan 1999), in the 1970s Siitoin was seriously organizing a militant far-right movement and tried to use every legal loophole available. He was well aware of the limitations set by the peace treaty, and, accordingly, tried to avoid labels like fascism or Nazism.

When interrogated in 1976, Siitoin stated that 'he belongs to the extreme right', but did not 'understand why he is called fascist'. Despite denying being a fascist, Siitoin claimed that the dictionary defines fascism as 'justice, discipline and order' and in that sense he might be a fascist (police interrogation 2/76, Supo). For Supo, Siitoin seemed hopelessly confused with his ideas about fascism and Nazism (PM 16.8.1977, KRP).

Siitoin also claimed that his party's uniforms do not relate to the uniforms of the banned 1930s movements, in spite of their identical colors (police interrogation 2/76, Supo). Later that year, Siitoin marched with swastika-flags, which irritated his Swedish cooperation partners: the Nordic Reich Party had used a sun cross in their demonstrations and thought showing swastikas is counterproductive (Kotonen 2015).

Siitoin built his party around his occultist hobbies. As he described, the occult society he had founded in the early 1970s was the first stage, through which the potential prospects could be forwarded to the more openly political groups. The ultimate purpose was 'to destroy communism', but this goal was to be revealed only at the later stages of political activity, and even then only 'as veiled, due to the peace treaty between Finland and Russia' (Siitoin to Claes Lantz, 15.1.1976).

Siitoin seemed to interpret the peace treaty more strictly than Supo; for the latter anticommunism was not necessarily of much interest or worrisome. This shows also in their analysis of Siitoin's activities, in which Supo referred to his fascist activities and the peace 
treaty but did not even mention the anti-Soviet propaganda as a possible cause for banning the organization (PM 16.8.1977, KRP). For the international far-right movement, anti-communism appeared occasionally as a respectable façade, behind which also more radical actions were carried out. For Siitoin, both fascism and anti-communism were potentially prosecutable offences and thus had to be veiled. However, when Siitoin noticed their activities were not banned, he started to act more openly.

In their analysis, Supo referred also to the misuse of freedom of speech (ibid.). Siitoin was indeed here very aware of his rights. To his local commander, Siitoin wrote that there is no law prohibiting' spreading their leaflets or using a Nazi-uniform; those acts are 'entirely legal'. Thus, he stated, 'the cat-and-mouse game may continue endlessly unless you attack the police' and 'now we just have to escalate the pace, because the constitution protects us'. (Siitoin to Tapani Pohjola 30.8.1977.) Using one's constitutional rights against the very rights constitution is supposed to protect is, of course, not atypical for the far-right organizations but often in fact constitutes their modus operandi (cf. Berbrier 1999).

Right under the nose of Supo and other authorities, Siitoin started to incite his supporters to terrorism. When the authorities finally banned his organization in 1977, he and his supporters launched, as they had promised, a terror campaign. An attempted bombing and a successful arson attack against a communist printing house, a letter bomb to the office of the communist youth organization and several other attacks followed. Subsequent prosecution and conviction eventually marked the end of Siitoin's party, although he continued as an active neo-Nazi in a different organization until his death in 2003.

Behind the bars, Siitoin continued his debate with the authorities, claiming that 'democracy is such a poor idea, that it cannot counter the rise of the far-right' and therefore has to use 'fascist' means (Siitoin to Urho Kekkonen, 21.6.1980). Siitoin now referred to his own ideology as 'neo-fascism', which, according to him, was not a violent ideology. Explicitly turning vice into virtue, Siitoin insisted that "quite often "bad" serves good and vice versa'. He described how they have managed to draw leftist voters, and how his party has disconnected the moderate right from the stigma of fascism. This way they helped, he argued, to uphold the capitalist system (Siitoin to Urho Kekkonen, 23.12.1979).

Retrospectively, it is apparent that Supo did not take Siitoin seriously enough. Because of the confusing use of terms and concepts, the uniform issue, occultism, and attention-seeking behaviour, the armed drills and openly stated terror threats were ignored. Often it is practically impossible to say whether confusion is intentional, or if Siitoin himself did not know the ideology that well either. Arguably, this is a problem that still exists. One may also ask whether authorities even recognize types of far-right terrorism, which often lack communicative aspect prevalent in other forms of terrorism (cf. Taylor 2013).

\section{Extremism in Finland: An Imported Product?}

The language used by the police reflected but also created political reality. Building upon what they knew about earlier movements limited their own expectations about how the far-right would evolve in the future. Somewhat paradoxically, it may even be the case that the officials who were themselves part of the earlier movements expected to see something similar with the rise of the extreme right, and when noticing dissimilarities between old and new groups they considered the new groups as harmless. Concepts and terms used thus guided them towards an outdated model and, to use the famous notion developed by Reinhart Koselleck (2004, $263 \mathrm{ff}$.$) , limited their horizon of expectation.$

At a time when linguistic conventions were not settled, there was plenty of room for innovation, especially when it came to terms like extremism. 'Fascism' and 'Nazism' were words to be used cautiously both by Supo and also by the far-right, although for different reasons. The 
new and unstable term 'extremism' thus appeared handy for them, even though the confusion obviously was often unintentional.

Criteria for identifying the new phenomena as extreme right, or as fascism or neo-Nazism were not at all clear in the police reports, and there was therefore also no consensus on which groups should be followed. Some patterns, however, stand out.

From a normative perspective, as defined in the peace treaty, one could suspect monitorable or even illegal activities if there were explicit links to foreign groups or ideologies, links to the former members of the banned organizations, or if the message was explicitly revolutionary, or if the use of violence or plans to that effect was organized. In some cases, open anti-Semitism also drew the attention of the police. However, extremism did not necessarily fall under these categories. Characteristic to the 'extreme right' was ultra-nationalism, or, depending on the analyst, patriotism. These concepts were seen mostly as conservative, not revolutionary. Rhetorically these conclusions were defended by the full scale of rhetorical redescriptions, from renaming and minimizing to turning vice into a virtue (Skinner 1997, cf. also Skinner 1989).

Until 1970s Supo's definitions of 'Nazism' or 'fascism' lacked the real point of reference, effectively meaning there was, for them, no neo-Nazism in Finland, let alone far-right terrorism. In November 1977 this all changed, although only momentarily, when a person belonging to Pekka Siitoin's organization conducted an arson attack and tried to use a bomb against a communist printing house. This act was described in the bourgeois press as terrorism (Kotonen 2018). Using the term 'terrorism' was however explained in this case by connecting it to the wave of terrorism abroad, especially by referring to the recent RAF terrorist acts in Germany. Foreign connection, albeit vague and based on analogy rather than on any actual links between the acts, was thus again used to explain away the events in Finland.

This has certain parallels with an interesting discussion on the use of the term 'terrorism' in Finland. There still prevails to some extent a 'persistent perception of the country as a bird's nest immune to outside turmoil' (Malkki \& Sallamaa 2018). Therefore, naming acts as terrorism tends to happen only when 'there is reason to suspect that it is linked with international networks widely characterized as terrorist elsewhere' (ibid.). Seeing terrorism essentially as an international phenomenon is typical to other countries as well. From this perspective, it is also perhaps telling that there are apparently no reports compiled by Supo dealing with the extreme right in the archives of the president Kekkonen before the early 1970s, even though reports on domestic communists were frequent (Rentola 2009, 74). The issue of far-right activism was mostly reported to the Ministers of Justice and Interior, or occasionally also to the Prime Minister, who all dealt with domestic issues, whereas foreign policy was in the hands of the president.

As has been noted by Quentin Skinner $(1989,20)$, studying the vocabulary used may provide insight into changing perceptions, awareness, and attitudes. When studying secretive or clandestine organizations or institutions, such as security police, which typically make their conceptual choices outside the public scrutiny, the analysis of the language used has even more stressed relevance. As this article has shown, the analysis of the concepts and their evolution may be useful also for understanding how the security threats are defined and constructed.

\section{Competing Interests}

The author has no competing interests to declare.

\section{References}

\section{Archival sources}

Archives of the Finnish Security Intelligence Servive (SUPO):

Pro memoria 16.5.1972, in subject file IXA1. 
"Extreme right movements in the Helsinki region", 1987, in subject file IXA1.

Ilm. 584/2.2.1962, in organization file jk I s-5.

PM 18.11.1966, Head of Supo Armas Alhava to the Secretary of Defense Supo Suorttanen, in organization file jk I s -5.

Anselmi Mäkelä, 10.3.1960, letter by Supo's office manager, in organization file jk II T 20 -2.

Ilm. 490/1.5.1974, in subject file IXA1.

Ilm. 3.4.1958/845, in subject file XIII C2.

Police investigation file 5/1966, in subject file XC.

Police interrogation 2/76 (23.4.76), in person file XIIIH-21346.

Police interrogation 2/76 (23.4.76), in person file XIIIH-21346.

Archives of the president Urho Kekkonen, Orimattila (UKA):

PM 29.8.1974, "Epäilty kansallissosialistinen järjestötoiminta Suomessa”, Supo 11.

Review $1 / 73$, Suojelupoliisi.

National Library of Finland (NLF), the correspondence of Pekka Siitoin:

Siitoin to Claes Lantz, 15.1.1976. COLL. 417.19.

Siitoin to Tapani Pohjola 30.8.77. COLL. 417.19.

Siitoin to Urho Kekkonen, 21.6.1980. Coll. 417.

Siitoin to Urho Kekkonen, 21.3.1979. Coll. 417.

National Bureau of Investigation (KRP):

PM 16.8.1977, Timo-Pekka Olavi Siitoinin poliittisesta ym toiminnasta, Suojelupoliisi. R $77 / 77$, archives of the National Bureau of Investigation.

\section{Printed and online sources}

Art, David. 2011. Inside Radical Right. The development of anti-immigrant parties in Western Europe. Cambridge: Cambridge University Press.

Backes, Uwe. 1989. Politischer Extremismus in demokratischen Verfassungsstaaten. VS Verlag: Wiesbaden. DOI: https://doi.org/10.1007/978-3-322-86110-8

Backes, Uwe. 2006. Politische Extreme. Eine Wort- und Begriffsgeschichte von der Antike bis in die Gegenwart. Vandenhoeck und Ruprecht: Göttingen. DOI: https://doi.org/ 10.13109/9783666369087

Backes, Uwe. 2009. Political Extremes: A conceptual history from antiquity to the present. London: Routledge. DOI: https://doi.org/10.4324/9780203867259

Berbrier, Mitch. 1999. "Impression management for the thinking racist". Sociological Quarterly 40: 411-433. DOI: https://doi.org/10.1111/j.1533-8525.1999.tb01727.x

Berger, J. M. 2019. "Researching Violent Extremism: The State of Play". Online: https:// resolvenet.org/research/researching-violent-extremism-state-play. DOI: https://doi.org/ $10.37805 /$ rve2019.3

Bjørgo, Tore, and Lars Erik Berntzen. 2019. "Typology of the Far Right". Radicalization Awareness Network. Accessed March 15. https://ec.europa.eu/home-affairs/sites/homeaffairs/files/ what-we-do/networks/radicalisation_awareness_network/about-ran/ran-local/docs/ ran_local_rotterdam_far_right_extermism_20190124_en.pdf.

Bötticher, Astrid. 2017a. "Towards Academic Consensus Definitions of Radicalism and Extremism". In: Perspectives on Terrorism 11(4): 73-77. 
Bötticher, Astrid. 2017b. Radikalismus und Extremismus: Konzeptualisierung und Differenzierung zweier umstrittener Begriffe in der deutschen Diskussion. Accessed March 14. https:// openaccess.leidenuniv.nl/bitstream/handle/1887/49257/FullText.pdf?sequence=1.

Buzan, Barry, Ole Wæver, and Jaap de Wilde. 1998. Security: A New Framework for Analysis. Boulder: Lynne Rienner Publishers.

Copsey, Nigel. 2004. Contemporary British Fascism: The British National Party and the Quest for Legitimacy. London: Palgrave. DOI: https://doi.org/10.1057/9780230509160

Ekberg, Henrik. 1991. Führerns trogna följeslagare - den finländska nazismen 1932-1944. Schildts: Helsinki.

Eriksson, Gunilla. 2016. Swedish Military Intelligence: Producing Knowledge. Edinburgh: Edinburgh University Press.

Faye, Guillaume. 2003. "The Cause of the Peoples?" Terre et Peuple 18.

Feldman, Matthew, and Paul Jackson. 2014. Doublespeak: Rhetoric of the Far-Right Since 1945. Stuttgart: ibidem-Verlag.

Feustel, Susanne. 2011. "Tendenziell tendenziös. Die staatliche Erfassung politisch motivierter Kriminalität und die Produktion der "Gefahr von links"”. In Elena Buck, Anne Dölemeyer, Paul Erxleben, Stefan Kausch, Anne Mehrer, Mathias Rodatz, Frank Schubert, Gregor Wiedemann (Hg.): Ordnung. Macht. Extremismus: Effekte und Alternativen des Extremismus-Modells, Forum für kritische Rechtsextremismusforschung 48: 143-162. Wiesbaden: VS Verlag. DOI: https://doi.org/10.1007/978-3-531-93281-1_7

Goschler, Contantin, and Michael Wala. 2015. "'Keine neue Gestapo". Das Bundesamt für Verfassungsschutz und die NS-Vergangenheit". Rowohlt: Reinbek.

Griffin, Roger. 2002. "The Primacy of Culture: The Current Growth (Or Manufacture) of Consensus within Fascist Studies". Journal of Contemporary History 37: 21-43. DOI: https://doi.org/10.1177/00220094020370010701

Hatzidaki, Ourania, and Dionysis Goutsos. (eds.) 2017. Greece in crisis: combining critical discourse and corpus linguistics perspectives. Amsterdam: John Benjamins Publishing Company. DOI: https://doi.org/10.1075/dapsac.70

Helsingin Sanomat. (19.9.2016) "Poliisiylijohtaja Kolehmainen kieltäisi uusnatsien tunnukset lailla: 'Lääkkeet taudin mukaan'”. Accessed March 15. https://www.hs.fi/kotimaa/art2000002921635.html.

Jackson, Sam. 2019. "Non-normative political extremism: Reclaiming a concept's analytical utility." Terrorism and Political Violence 31(2): 244-259. DOI: https://doi.org/10.10 80/09546553.2016.1212599

Kaplan, Jeffrey. 1999. "The Finnish New Radical Right in Comparative Perspective”. In Kyösti Pekonen (ed.). The New Radical Right in Finland. Helsinki: University of Helsinki Press.

Koselleck, Reinhart. 2004. Futures Past: On the Semantics of Historical Time. New York: Columbia University Press.

Kotonen, Tommi. 2015. "Suomalainen syksy - Äärioikeiston poliittinen väkivalta 1970-luvun Suomessa". Kosmopolis 3/2015.

Kotonen, Tommi. 2018. Politiikan juoksuhaudat. Äärioikeistoliikkeet Suomessa kylmän sodan aikana. Jyväskylä: Atena.

Lipset, Seymour. 1960. Political man: the social bases of politics. New York: Doubleday.

Lipset, Seymour, and Earl Raab. 1970. The Politics of Unreason: Right Wing Extremism in America, 1790-1970. Chicago: University of Chicago Press.

Lööw, Heléne. 2017. "Våldsbejakande extremism: begrepp och diskurs". In SOU 2017:67, Våldsbejakande extremism: en forskarantologi. Stockholm: Regeringskansliet.

Lucardie, Paul. 2014. Democratic extremism in theory and practice: all power to the people. London: Routledge, 2014. DOI: https://doi.org/10.4324/9781315857558 
Lyon, David. 2007. Surveillance Studies. An Overview. Cambridge: Polity Press.

Malkki, Leena, and Daniel Sallamaa. 2018. "To Call or Not to Call It Terrorism: Public Debate on Ideologically-motivated Acts of Violence in Finland, 1991-2015". Terrorism and Political Violence 30(5): 862-881. DOI: https://doi.org/10.1080/09546553.2018.1447 191

Marcus, Jonathan. 1995. The National Front and French Politics: The Resistible Rise of Jean-Marie Le Pen. New York: NYU Press.

Mosse, George. 1980. Masses and Man: Nationalist and Fascist Perceptions of Reality. New York: Howard Fertig.

Mudde, Cas. 2002. The Ideology of the Extreme Right. Manchester: Manchester University Press. DOI: https://doi.org/10.7228/manchester/9780719057939.001.0001

Mudde, Cas, and Luke March. 2005. "What's left of the radical left? The European radical left after 1989: decline and mutation". Comparative European Politics 3(1): 23-49. DOI: https://doi.org/10.1057/palgrave.cep.6110052

Onursal, Recep, and Daniel Kirkpatrick. 2019. "Is Extremism the 'New' Terrorism? the Convergence of 'Extremism' and 'Terrorism' in British Parliamentary Discourse”. Terrorism and Political Violence. DOI: https://doi.org/10.1080/09546553.2019.1598391

Oppenhäuser, Holger. 2011. "Das Extremismus-Konzept und die Produktion von politischer Normalität". In Elena Buck, Anne Dölemeyer, Paul Erxleben, Stefan Kausch, Anne Mehrer, Mathias Rodatz, Frank Schubert, Gregor Wiedemann (Hg.): Ordnung. Macht. Extremismus: Effekte und Alternativen des Extremismus-Modells, 35-58. Forum für kritische Rechtsextremismusforschung, 48. Wiesbaden: VS Verlag. DOI: https://doi. org/10.1007/978-3-531-93281-1_2

Pohjonen, Juha. 1999. "Suojelupoliisi - sisäisen turvallisuuden takaaja". In Matti Simola, and Tuula Sirviö (eds.). Isänmaan puolesta - Suojelupoliisi 50 vuotta, 69-112. Gummerus: Helsinki.

Rentola, Kimmo. 1997. Niin kylmää että polttaa. Kommunistit, Kekkonen ja Kreml 1947-1958. Helsinki: Otava.

Rentola, Kimmo. 1999. "Punaisen Valpon synty". In Matti Simola, and Tuula Sirviö (eds.). Isänmaan puolesta - Suojelupoliisi 50 vuotta, 45-68. Gummerus: Helsinki.

Rentola, Kimmo. 2009. “Suojelupoliisi kylmässä sodassa”. In Matti Simola (ed.). Ratakatu 12 Suojelupoliisi 1949-2009, 9-192. WSOY: Helsinki.

Shekhovtsov, Anton. 2018. Tango Noir. Russia and the Western Far Right. London: Routledge. DOI: https://doi.org/10.4324/9781315560991

Silvennoinen, Oula, Marko Tikka, and Roselius Aapo. 2016. Suomalaiset fasistit: mustan sarastuksen airuet. Otava: Helsinki.

Sisäasiainministeriö. 2012. Kansallinen toimenpideohjelma väkivaltaisen ekstremismin ennaltaehkäisemiseksi. Helsinki. Julkaisu 28/2012.

Skinner, Quentin. 1989. "Language and Political Change". In Terence Ball, James Farr, Russell L. Hanson (eds.). Political Innovation and Conceptual change. Cambridge: Cambridge University Press.

Skinner, Quentin. 1997. Reason and Rhetoric in the Philosophy of Hobbes. Cambridge: Cambridge University Press. DOI: https://doi.org/10.1017/CBO9780511598579

Sörbom, Adrienne, and Magnus Wennerhag. 2016. "Begreppet extremism - en kritisk introduktion". DOI: https://doi.org/10.13068/2000-6217.5.1

SOU 2002:91. Hotet från vänster. Säkerhetstjänsternas övervakning av kommunister, anarkister m.m. 1965-2002. Stockholm: Regeringskansliet.

SOU 2002:94. Övervakningen av nazister och högerextremister. Säkerhetstjänst, nazism och högerextremism 1946-1980. Stockholm: Regeringskansliet. 
SOU 2013:81. När vi bryr oss. Förslag om samverkan och utbildning för att effektivare förebygga våldsbejakande extremism, betänkande av Utredningen om ett effektivare arbete för att förebygga våldsbejakande extremism. Stockholm: Regeringskansliet.

Stortinget. 1996. Rapport til Stortinget fra kommisjonen som ble oppnevnt av Stortinget for å granske påstander om ulovlig overvåking av norske borgere ("Lund-rapporten»). Accessed March 15. https://www.stortinget.no/no/Saker-og-publikasjoner/Publikasjoner/Dokumentserien/1995-1996/Dok15-199596/.

Taylor, Max, Donald Holbrook, and PM Currie. 2013. Extreme Right-Wing Political Violence and Terrorism. London: Continuum Press.

Treaties of peace with Italy, Bulgaria, Hungary, Rumania, and Finland. 1947. Washington, D.C.: U.S. Government Printing Office.

Vaarakallio, Tuula. 2015. "The Borderline between Parliamentary and Extra-Parliamentary Rhetoric: The Case of the Populist (True) Finns Party". In Suvi Soininen and Tuula Vaarakallio (eds.), Challenges to Parliamentary Politics: Rhetoric, Representation and Reform, 99-124. Baden-Baden: Nomos Verlag. DOI: https://doi.org/10.5771/9783845265001-99

Virchow, Fabian. 2017. “"Rechtsextremismus”: Begriffe - Forschungsfelder - Kontroversen”. In Virchow, Fabian, Martin Langebach, and Alexander Häusler (Hrsg.): Handbuch Rechtsextremismus, 5-41. Springer Verlag. DOI: https://doi.org/10.1007/978-3-53119085-3_2

Warrington, Anna. 2018. "Sometimes you just have to try something'- A critical analysis of Danish state-led initiatives countering online radicalization". Journal for Deradicalization 14: 111-152.

How to cite this article: Kotonen, Tommi. 2020. "Terminological Games: The Finnish Security Police Monitoring the Far-Right Movements in Finland During the Cold War." Redescriptions: Political Thought, Conceptual History and Feminist Theory 23(1): 54-70. DOI: https://doi.org/10.33134/rds.319

\section{Submitted: 11 February 2020 Accepted: 22 June 2020 Published: 13 July 2020}

Copyright: $\odot 2020$ The Author(s). This is an open-access article distributed under the terms of the Creative Commons Attribution 4.0 International License (CC-BY 4.0), which permits unrestricted use, distribution, and reproduction in any medium, provided the original author and source are credited. See http://creativecommons.org/licenses/by/4.0/. 